\title{
Formation of complex model of analytical support of deposit bank management
}

\section{Iryna D'yakonova}

Doctor of Economic Sciences, Professor, Director of Education and Research Institute Business Technologies "UAB", Sumy State University, Ukraine

\section{Anatoliy Guley}

Doctor of Economic Sciences, Professor, Banking Institute / College of Banking, Praha, Czech Republic; Ternopil National Economic University, Ukraine; Chief Executive Officer of PJSC "Ukrainian Interbank Currency Exchange“, Ukraine

\section{Asiiat Sheliuk}

Ph.D., Assistant of the Department of International Economics, Sumy State University, Ukraine

(C) The Authors, 2017. This article is published with open access at ARMG Publishing.

\begin{abstract}
The effectiveness of the deposit bank management, as individual decision making in the management process involving the deposit resources is largely determined by the efficiency, completeness, timeliness and adequacy of methods and analysis techniques used in its implementation. Perfection analysis, in turn, depends on the existing methodological framework, information analysis.

It does not require evidence of the fact that the development of any economic system can not be effective and successful without a detailed analysis of the achieved level, determining the future prospects and goals and finding appropriate ways to achieve this goal, and the realization of each of these challenges requires an appropriate analytical support.

Implementation of all functions of the deposit bank management should include: analysis of macro functioning of the bank using SLEPT, STEP and PEST analysis; comprehensive analysis of the external and internal environments using bank SNW, SPASE and SWOT analysis; using micro-bank financial, statistical, mathematical economic analysis and should be accompanied by a risk analysis via expert methods, GAP-analysis, duration analysis, VAR-analysis, stress testing and back.
\end{abstract}

Keywords: banking system, bank, banking, banking management, deposit bank management, complex model analytical support, SWOT analysis, deposit policy.

JEL Classification: G20, G21, G32.

\section{Introduction}

The efficiency of the deposit bank management, as well as individual decision making in the management of the deposit resources attracting process is largely determined by the efficiency, completeness, timeliness and adequacy of methods and analysis techniques used in its implementation.

In modern conditions of deposit activity the multi-vision, high competition and unstable environment, the role and significance of analytical procedures increases. Analytical support is an integral part of the management of the bank's activities in general and deposit management, in particular. It should be noted that deposit management cannot allow lack of information, because deposit activity is accompanied by a large number of risks affecting its results, efficiency and financial condition.

Thus, the formation of an efficient system of deposit management is not possible without creating analytical support that would solve the tasks of supporting management decisions, finding existing or potential problems and solutions, assess progress and prospects and so on.

Outlined above determines keen interest of scientists to study the financial and economic analysis of the banks. The link of the financial and economic analysis and banking management is fully and reasonably de- 
scribed in the scientific and academic literature and, despite some contradictions in the approaches and classifications, we can say that the authors made a clear conclusion of the importance of financial and economic analysis for the implementation of management functions. The authors noted that the analysis is the most important among these functions, because it provides their implementation at all levels of the management process. The problem of analysis research in the system of banking management dedicated to a series of studied by known Ukrainian and foreign authors, including M. Bakanov, A. Gerasimovitch, I. Karakoz, V. Paliy, O. Petruk, L. Prymostky, V. Samborska, A. Sheremet, M. Chumachenko and others.

Theoretical principles formed, methods and tools of analysis used in the implementation of the deposit bank management functions are insufficient, due to the fact that the object field is almost eliminated the risks of deposit money deposit management; there is no development of the analysis of the external factors influences on the deposit management goals achievement, etc.

As such, the task to form a complex model of analytical support of the deposit management, based on the maximum accounting of the specific objects of analysis to justify the necessary analytical tools.

The analysis of scientific literature demonstrates the ambiguity in the use of terms: "information provision" (O. Lupus, N. Rushchyshyn, T. Andreikiv, M. Vahrushyna, D. Konduell, John. Foster, A. Sheremet ) "information field" (O. Kaverina, V. Chernov, G. Prymostka) "analytical information system" (M. Zubok, L. Horuzhy, S. Shershenova) "accounting and analytical support" (A. Alekseyeva, I. Alekseeva, J. Bohataya, S. Boronenkova, M. Vahrushyna, O. Nikolaeva, V. Radchenko, F. Ripol-Zaragoza, C. Ward), "analytical support" (A. Ionov, G. Savitskaya, N. Seleznev).

It should be noted that in the current bank analysis is not just an element of an effective deposit management, but its basis.

The deposit management analysis helps to evaluate the external environment in which the bank operates, competitive challenges, internal capabilities and needs, and therefore, a precondition for taking any operational decisions. The legislative or regulatory restrictions protect banks from excessive risk, unfair competition, fraud and bankruptcy and acts as the factors of external regulation of deposit activity. The analysis, audit and control (and the last two elements are based on the analysis) is an internal regulation (self-regulation).

The analysis is carried out before making the management decision, during and after it to assess the results. That is way the financial and economic analysis of the deposit and deposit facilities management is one of the basic conditions for ensuring the quality and effectiveness of management decisions.

The main objectives of the analysis are to implement the functions of deposit management, overall estimation of the efficiency and effectiveness of the deposit activity.

The experience of the most successful and best-known banks in the world proves the importance of analyses in the system of bank deposit management. The use of modern technology and advanced management tools of analytical research is a guarantee of successful banks deposit activity and enhances the effectiveness of deposit management in a changing environment.

In addition it should be noted that most scientists point to the existence of the relationship between the analysis and the deposit activity management process and deposit management system. The investigation of the specifics of the deposit activity proves that the process of management in the banks today at all levels of governance (banking system, the bank, branch of the bank) is based on analytical studies.

Thus, the main conclusion that can be made is the fact that, first, analytical support should be considered as an important component of a bank management system as a whole, and, secondly, that the definition "analytical support" reflects the content of the necessary procedures to collect, organize, analyze, store and use information that forms the deposit process management as a continuous sequence of management solutions to achieve the operational, tactical and strategic objectives and goals.

Summarizing the developments in this area, we believe that analytical support in deposit management is a combination of the analytical information, methods of its processing, analysis and forms of presentation, as well as organizational, methodological and intellectual activity in gathering, organizing, analyzing, storing and using of information. These procedures allow to form the process of the deposit management as a continuous sequence management solutions to achieve these goals. 
The purpose of analytical support of deposit management is to support the process of deposit management at all stages and evaluate the effectiveness of its implementation.

In this context, we can distinguish the following tasks: the analysis of the implementation of the functions of deposit management and the analysis of the effectiveness of deposit management. We propose to specify the tasks of analytical support of the deposit management by the management functions, including:

$>$ determine the impact of the results of the bank deposit activity on the level of its financial stability;

$>$ specify the effectiveness of the bank deposit management, identification of the reserves to increase the effectiveness and taking steps to use the identified reserves;

$>$ underline the availability of bank resources (financial, technical, human, etc.);

$>$ define the needs of the bank in deposit resources;

$>$ estimate the average cost of deposit resources of the bank and their individual components;

$>$ designate the cost of for opening and turnover of bank accounts of customers and their cash management services;

$>$ define the stability and the turnover of the deposit bank resources in general and its separate components;

$>$ identify the acceptance of the objective deposit management with the substance of transactions;

$>$ determine the impact of external factors and internal conditions on the results of bank deposit activity;

$>$ compare the objectives of the bank and the current market conditions and the specific products and services requirements;

$>$ monitor the compliance with bank reserve requirements on NBU correspondent accounts with the NBU and regulation ratios set by the NBU, including liquidity standards;

$>$ justify the selection of strategic alternatives to bank deposit policy;

$>$ assess the price and non-price parameters of bank operations to attract customer funds its capabilities and goals;

$>$ evaluate all bank risks associated with the formation of deposit bank resources;

$>$ assess the competitive position of the bank on the deposit services market;

$>$ compare the final results of the bank and resources; set goals and got the final result of its implementation.

It necessary to review the analytical tools of the providing of deposit management, which is defined as a set of types, approaches, techniques and methods of the analysis of the deposit management facilities.

A significant set of techniques of analytical procedures is not always allow to achieve an effective analysis. We believe that an effective analysis of the system deposit management involves the selection of the instruments that will perform tasks with the lowest cost of financial, human resources in a shorter period.

Summarizing the development of researchers on the subject, we offer analytical support to implement the bank deposit management based on the model presented in Figure 1 (see in Appendix).

Based on the author's approach and considering multidimensional and multilevel nature deposit activity of the bank, the system of deposit facilities management was formed.

According to the formal deposit facilities management we can distinguish the unit of the objects of deposit analysis, including processes, resources, assessment of the administrative officials, professionals, performers and block of its results (volume of attracted resources, deposit risks, the efficiency of the deposit activity and the effectiveness of the deposit management). Formalizing deposit management facilities allows to create object field of its analytic software.

It should be noted that the objects of the analytical investigation, in the most general terms, is not only the deposit activity and its results (deposit resources and the deposit risk), as well as factors that influence on the macro-, meso- and microlevels.

In addition, the formalization of analytical support facilities should consider the information field of analytical studies. During the research the need to specify analytical research facilities, which depends on the subject, purpose and objectives of the research period of the management process, specific administrative procedures applied, the volume of information available, raises.

For deep analytical research we propose to use the formed system of deposit facilities management with the highlighting the objects of analytical support on different levels of their manifestation. 
An important analytical support for the formation of deposit management is the determination of its subjects, the composition of which includes those which use the analysis to justify management decisions at the strategic, tactical and operational levels (these are the subjects of banking management in general and deposit management, in particular).

Analytical support technology of deposit management not only ensures that tasks supporting the implementation of its functions and effectiveness, but also considers the adaptive nature. Thus, for the purposes of deposit bank management effective technologies of analytical support, presented in Figure 2 (see in Appendix) are important.

The technology of analytical support of bank deposit management is based on an adaptive approach that maximizes impact analysis procedures and achieve desired results with minimal resources (financial, labor, time, etc.) by selecting each block of technology elements that correspond to the task.

The system of effective analysis of deposit management involves the selection of appropriate tools, allowing achieving the objectives and implementing tasks with the least amount of time financial and human resources. This analytical tools should be selected based on the objectives (block of Targeting), based on filtered information that meets adequacy, relevance, relevance, relevance, completeness, etc. (block of adaptive filtering information), and consider the possibility of proper information processing (block of analytical procedures) and enforce the objectives and development of recommendations on the results (power results).

Thus, the given model allows to choose the instruments of analysis based on the objective field of deposit management, while forming of information field research is limited to the task.

Based on the specified object field of analytical support of deposit management, it is necessary to form a matrix selection of tools of analytical support. The choice of tools for sub-block analysis of the external environment (macro- and mesolevel) is shown in Table 1.

To study the environment of deposit management at the macrolevel, it is proposed to use SLEPT, STEP and PEST analysis and comprehensive analysis of the external and internal environments functioning of the bank by SNW, SPASE and SWOT analysis.

The functioning of research environment of the bank can be carried out through indirect and direct factors of influence and application of PEST-analysis. The results of this study generate environment opportunities and risks.

Table 1. The analysis of tools in environment of the bank for deposit facilities management

\begin{tabular}{|c|c|c|c|c|c|}
\hline \multirow[b]{4}{*}{ 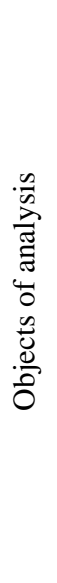 } & \multicolumn{5}{|c|}{ Environment } \\
\hline & Macrolevel & \multicolumn{4}{|c|}{ Mesolevel } \\
\hline & & \multicolumn{2}{|c|}{ Customers } & Competitors & Regulator \\
\hline & $\begin{array}{l}\text { Political, economic, } \\
\text { social, demographic } \\
\text { factors }\end{array}$ & $\begin{array}{l}\text { Marketing as- } \\
\text { pects (quantita- } \\
\text { tive and qualita- } \\
\text { tive analysis of } \\
\text { client base, } \\
\text { forming an ef- } \\
\text { fective customer } \\
\text { segmentation) }\end{array}$ & $\begin{array}{l}\text { Financial aspects (the } \\
\text { number of customer } \\
\text { accounts, the number } \\
\text { of open and closed ac- } \\
\text { counts, balances on } \\
\text { accounts, distribution } \\
\text { of customer funds by } \\
\text { type of deposit, asset } \\
\text { allocation between } \\
\text { bank customers in } \\
\text { volume and types of } \\
\text { investments) }\end{array}$ & $\begin{array}{l}\text { The overall level of com- } \\
\text { petition in the market, } \\
\text { banks, competitors }\end{array}$ & $\begin{array}{l}\text { Regulatory field, } \\
\text { rules of deposit } \\
\text { operations }\end{array}$ \\
\hline 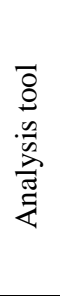 & $\begin{array}{l}\text { SLEPT, STEP, PEST } \\
\text { analysis; integrated } \\
\text { analysis of environ- } \\
\text { ment using bank } \\
\text { SNW, SPASE, } \\
\text { SWOT } \\
\text { analysis }\end{array}$ & $\begin{array}{l}\text { Financial, statis- } \\
\text { tical, economic } \\
\text { and mathematical } \\
\text { analysis, risk } \\
\text { analysis using } \\
\text { expert tech- } \\
\text { niques, stress and } \\
\text { back-testing }\end{array}$ & $\begin{array}{l}\text { Financial, statistical, } \\
\text { economic and mathe- } \\
\text { matical analysis, risk } \\
\text { analysis using expert } \\
\text { methods, gap-analy- } \\
\text { sis, duration analysis, } \\
\text { var-analysis, stress } \\
\text { testing and back }\end{array}$ & $\begin{array}{l}\text { PEST analysis; compre- } \\
\text { hensive analysis of the ex- } \\
\text { ternal and internal envi- } \\
\text { ronments using bank } \\
\text { SNW, SPASE and SWOT } \\
\text { analysis }\end{array}$ & $\begin{array}{l}\text { Comprehensive } \\
\text { analysis of external } \\
\text { and internal envi- } \\
\text { ronments using } \\
\text { bank SNW, SPASE } \\
\text { and SWOT analysis }\end{array}$ \\
\hline
\end{tabular}

Source: summarized by authors. 
These approaches can be used to analyze the competition, the results of which are formed conclusions about the strengths and weaknesses of their deposit management.

To assess compliance deposit policy possible changes in the environment is appropriate SWOT-analysis that assessed the success of the bank on the basis of identified threats and potential. According to the results can justify the ways of strengthening benefits or create new ones, and find a way to protect against the risk (or identify critical risks that can be fatal to the bank).

The choice of tools for sub-block analysis of the internal environment of micro shown in Table 2.

Table 2. The analysis of tools in internal environment of the bank for deposit facilities management

\begin{tabular}{|c|c|c|c|c|c|c|}
\hline \multirow[b]{2}{*}{ 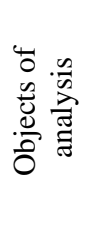 } & \multicolumn{6}{|c|}{ Internal environment } \\
\hline & $\begin{array}{l}\text { Internal fac- } \\
\text { tors affecting } \\
\text { deposit } \\
\text { activity }\end{array}$ & $\begin{array}{l}\text { Deposit re- } \\
\text { sources }\end{array}$ & $\begin{array}{l}\text { Processes } \\
\text { (design, devel- } \\
\text { opment, pro- } \\
\text { motion and } \\
\text { marketing) }\end{array}$ & Risks of deposit & $\begin{array}{l}\text { The effectiveness } \\
\text { of the deposit }\end{array}$ & $\begin{array}{l}\text { The effectiveness } \\
\text { of the deposit } \\
\text { management }\end{array}$ \\
\hline 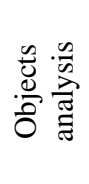 & $\begin{array}{l}\text { SNW, SPASE } \\
\text { and SWOT } \\
\text { analysis }\end{array}$ & $\begin{array}{l}\text { Financial, sta- } \\
\text { tistical, eco- } \\
\text { nomic and } \\
\text { mathematical } \\
\text { analysis }\end{array}$ & $\begin{array}{l}\text { Financial, sta- } \\
\text { tistical analysis }\end{array}$ & $\begin{array}{l}\text { Expert methods, } \\
\text { GAP-analysis, dura- } \\
\text { tion, VAR-analysis, } \\
\text { stress testing and back }\end{array}$ & $\begin{array}{l}\text { Financial, statisti- } \\
\text { cal, economic and } \\
\text { mathematical anal- } \\
\text { ysis, BSC }\end{array}$ & $\begin{array}{l}\text { Financial, statisti- } \\
\text { cal, economic and } \\
\text { mathematical anal- } \\
\text { ysis, BSC }\end{array}$ \\
\hline
\end{tabular}

Source: summarized by authors.

To study the internal environment of the bank in the deposit management authors proposed to use SNW, SPASE and SWOT analysis, which are complex methods that allow to evaluate factors of external and internal environment in the sector, identify strengths, neutral and weaknesses of the bank (SNW analysis) to evaluate the current situation and create or adjust the deposit policy of the bank (SPASE analysis), SWOT analysis and so on.

The analysis of the gap in resources and competencies of the bank and expected changes in the environment the bank can determine the necessary changes in the deposit policy.

At the risk of deposit it is appropriate to use a classification developed in the first section. To assess the risk of deposit activity, GAP-analysis, duration, VAR-analysis, stress testing and back should be applied.

To be effective, deposit management, in addition to traditional indicators of financial, statistical, economic and mathematical analysis, determining the level of expenses for fundraising, efficiency allocation of borrowed funds, etc., uses a balanced system of indicators (BSC).

Considering the modified versions of BSC, one could argue that it can be considered as a universal tool among existing ones, allowing to align tactical and strategic objectives of the bank deposit, the most fully appreciate the results, their relationship with the key (priority) performance indicators and the potential of the bank.

On this basis, and given that BSC allows to structure the information flows that impact on improving the quality of information provision and management's performance of their duties, as well as the efficiency of the bank as a whole, this system should be seen at the base forming analytical support planning of deposit of the bank.

Thus, the thesis that the deposit management bank is based on adaptive approach requires appropriate analytical support, seen as a set of analytical information, methods of processing, analysis and forms of presentation, as well as organizational, methodological and intellectual activity with collecting, organizing, analyzing, storing and using information that allows you to create a deposit process management as a continuous sequence of managerial decisions aimed at achieving certain goals is proved.

Analytical tools of management receives the deposit depending on the specific object of analysis and management functions. When planning the proposed use of predictive tools to create adaptive nature of the deposit policy and strategy of the bank, in coordination with general banking strategy; in the control - descriptive tools to monitor and detect abnormalities, including the established routine of deposit options and determine their causes; for the implementation of regulatory functions - normative instrument, results of which will justify the necessary managerial influences. 


\section{References}

1. D’yakonova, I., Mordan Y. (2015). Risk Governance and Control: Financial Markets \& Insti tutions journal, Publishing House "Virtus Interpress", 3(1), 325-335.

2. Global financial stability report of International Monetary Fund (April, 2011). Chapter 2: How to address the systemic part of liquidity risk, pp. 75-110.

3. Hirtle, B., Schuermann, T., Stiroh, K. (2009). Macroprudential Supervision of Financial Institutions: Lessons from the SCAP. Federal Reserve Bank of New York Staff Reports, № 409, 15 p.

4. Karcheva, G. (2014). Stress testing of banks: theory and practice. Economics and management: problems of science and practice: Collection of scientific articles, 2, Verlag SWG imex GmbH, Nürnberg, Deutschland, pp. 71-76.

5. Kukukina, I.G. (2008). Upravlencheskyi Uchet: Upravlenye Zatratamy. Upravlencheskyi Analiz: Uchebnik [Managerial Accounting: Cost Management. Managerial Analysis: Textbook]. M.: Higher Education, $418 \mathrm{p}$.

6. Peruško, T., Zenzerović, R. (2011). Designing the deposits management model in function of banking activities optimization, Croatian Operational Research Review, 2, 112-121.

7. Yvashkevych, V.B. Bukhhalterskyi upravlencheskyi uchet. Uchebnyk [Accounting management accounting. Textbook]. M.: Mahystr, 574 p.

8. Vovchak, O.D., Rushchyshyn, N.M., Andreikiv, T.Ia. (2008). Kredyt i bankivska sprava: pidruchnyk [Credit and banking: a textbook]. K.: Znannia, 564 p.

\section{Appendices}

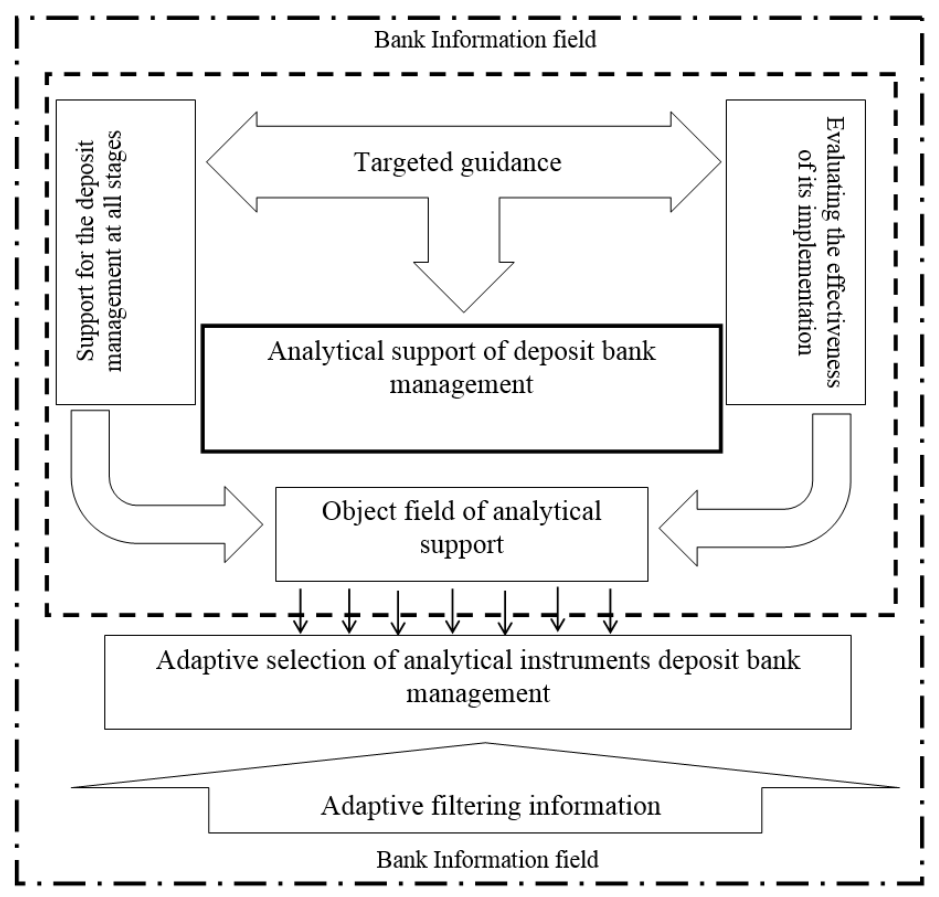

Source: summarized by authors.

Figure 1. Model of analytical support of deposit bank management 


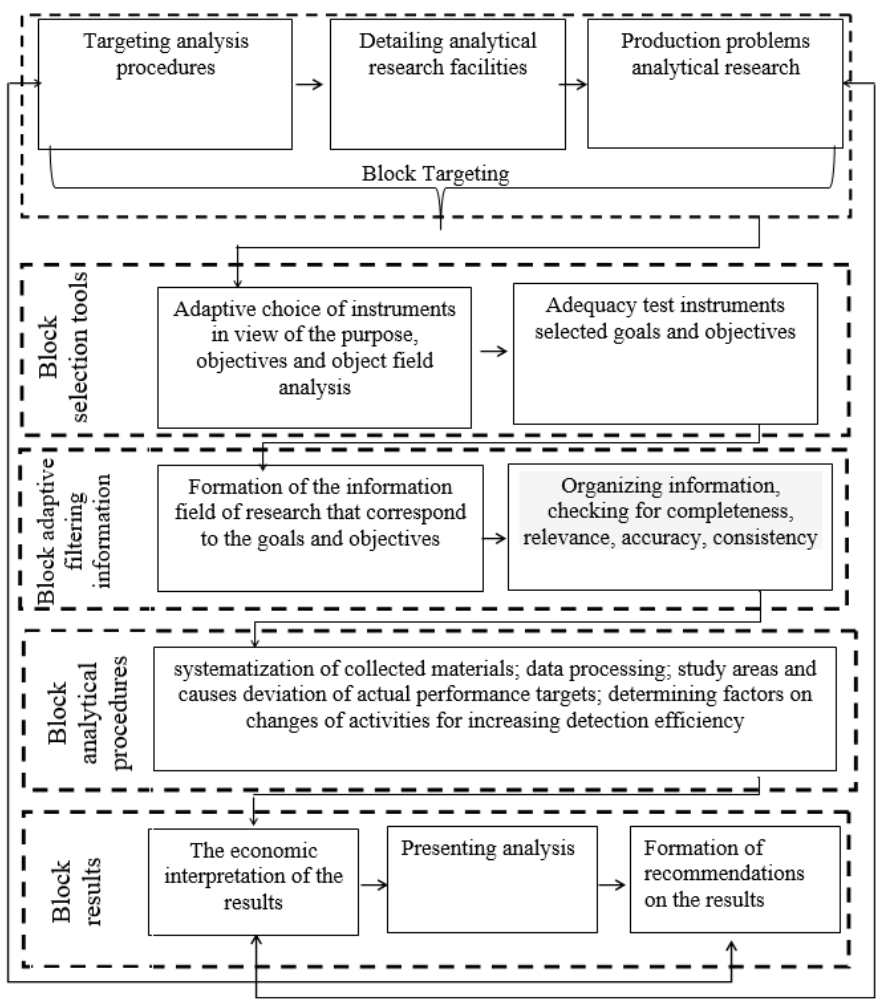

Source: summarized by authors.

Figure 2. Technology of analytical support of deposit bank management, built on the basis of adaptive approach 